\title{
CONSIDERATIONS REGARDING THE PROCEDURE FOR THE ACCESS TO PUBLIC INTEREST INFORMATION IN ROMANIA AND BULGARIA
}

\author{
G. Varia
}

\author{
Gabriela Varia \\ Postdoctoral Researcher \\ University of Bucharest, Bucharest, Romania \\ *Correspondence: Gabriela Varia, NUPSPA, Povernei 6, \\ Bucharest, Romania \\ E-mail: gabrielavaria@snspa.ro / gabrielavaria@yahoo.com
}

\begin{abstract}
By means of this article, we undertake to perform an analysis of the procedure regarding the citizens' access to public interest information in Romania and in Bulgaria, thus attempting to illustrate the common points and the interaction elements occurring between them, as both states joined the European Union in the same period.
\end{abstract}

Keywords: access to information of public interest, human rights, democracy.

\section{Introduction}

Free and unrestricted access to any public interest information, thus defined through the Romanian Law no. 544/2001, constitutes one of the main fundamental principles of the relationships between persons and public authorities, according to the Romanian Constitution and to the international documents ratified by the Romanian Parliament. ${ }^{l}$

The fundamental law of Romania receives the right to information from the international legal instruments in the field ${ }^{2}$, it being considered a truly fundamental right because man's material and spiritual development, the exercise of the freedoms established through the Constitution and especially of those through which are expressed the thoughts, opinions, beliefs of any kind, also involve the possibility to receive data and information regarding the social, political, economic, scientific and cultural life. ${ }^{3}$ Thus, the content of the right to information, as defined in article 31 of the Romanian Constitution, comprises: the person's right to by informed promptly, correctly and clearly with respect to the measures envisaged and especially taken by the public authorities; free access to the sources of public information, scientific and technical, social, cultural, sportive; the person's possibility to directly and normally receive the radio and television broadcasts; the governmental authorities' obligation to create the material and legal conditions for the free and ample broadcasting of information of any kind. ${ }^{4}$

\footnotetext{
${ }^{1}$ E. Bălan, Procedura administrativă, Universitara Publishing House, Bucharest, 2005, p. 164.

${ }^{2}$ For example, recommendation (2002)2 of the Committee of Ministers to member states on access to official documents, adopted by the Committee of Ministers on 21 February 2002 at the $784^{\text {th }}$ meeting of the Ministers' Deputies.

3 Elena-Simina Tănăsescu in Constantinescu, M. \& all, (2004), The Constitution of Romania Reviewed Commentaries and Explanations, All Beck Publishing House, Bucharest, 2004, p. 64.

${ }^{4}$ I. Muraru in Muraru, I., Tănăsescu, E.S., (coord.), The Constitution of Romania commented article by article, C.H. Beck Publishing House, Bucharest, 2008, p. 300.
} 


\section{The access to public interest information in Bulgaria}

In Bulgaria, by free access to public interest information is understood any information regarding social life in the Republic of Bulgaria, as well as the offering of the citizens' possibility to have their own opinion regarding the activities of the persons having the obligations deriving from the law. ${ }^{5}$

The Bulgarian Access to Public Information Act regarding free access to the public interest information applies for the access to the public interest information which is created and maintained by the state bodies, with regional and local offices. The law does not apply to information of a personal nature. The institutions in the public sector must supply public interest information.

According to the law, any citizen of the Republic of Bulgaria has the right to access public interest information; at the same time, the legal persons and the foreign citizens, as well as the persons without citizenship, also enjoy this right, but with some restrictions. Thus, the right to public interest information and the right to re-use the information in the public sector cannot be exercised against the rights and reputation of others, as well as against national security, public, national order, health and moral standards.

The basic principles that govern this law are the following: openness, correctness and the exhaustiveness of information, the assurance of the legal conditions for accessing public interest information, the assurance of conformity with the legislation, the process of searching and receiving public interest information, the protection of access to information, personal character data protection and the guarantee of security of society and state.

The citizens' access to public interest information may be partial or total.

According to Bulgarian law, public information created and kept by their bodies and administrative structures is divided into official and administrative information. Thus, official information is considered as being the information contained in the self-government state or local documents in the course of exercising their duties." Next article states that the administrative information will be considered information that is collected, created and maintained in connection to the official information, as well as within the activity of their bodies and administrative structures.

Access to the official information contained in normative acts will be accessed by means of promulgating them. According to the Bulgarian law, access to the administrative information must be unlimited. It cannot be unlimited in the following cases: when it pertains to the activity of preparing a document of the bodies and has no legal significance in itself (approvals and recommendations prepared by or for a body, reports and consultations) or when it contains opinions and statements regarding the ongoing or prospective negotiations.

The petition to grant access to interest public information can be made in the form of a written or oral request, the petition being considered written when sent in electronic format.

In case the petitioner does not receive an answer to the verbal request, he/she may draft a written petition, which must contain the following information (art. 25): the petitioner's full name, or, respectively, name and headquarters; description of the information requested; preferred form of access to the information requested; the petitioner's correspondence address.

The access to public interest information is granted in the following forms: Examination of the information - original or copy; Verbal - explanation; Paper copy; Copied on a technical media. The persons with disabilities of sight, hearing or speech have the right to request the information in a form that corresponds to their ability to communicate.

\footnotetext{
${ }^{5}$ Access to Public Information Act, promulgated in State Gazette No. 55/7 July 2000, with amendments.

${ }^{6}$ Article 10 of the Access to Public Information Act, promulgated in State Gazette No. 55/7 July 2000, with amendments.
} 
The requests regarding public interest information will be solved in the shortest possible time, but no later than 14 days since the date of registration; the term may be exceeded by 10 days when the information is substantial in volume and requires more time to prepare.

Access to public interest information must be free of charge. A decision of refusal to grant access to public interest information must indicate the legal and factual reasons for the refusal, on the grounds of the act, decision date and the appeal procedure.

The public interest information must be published on the institution's website, in the mass-media, but also at the institution headquarters. In case of refusal to supply the information requested by the citizens, for reasons not pertaining to the legislation in effect, for reasons of discrimination, fines are charged.

\section{Comparative analysis}

In Bulgaria, as well as in Romania, free access to public interest information applied for the activities, or derives from the activities, of a public authority or public institution. In exchange, in Romania is also offered access to personal character information, as long as it pertains to an identified or identifiable individual ${ }^{7}$ while in Bulgaria the law does not apply to the personal character information.

Both in Romania, and in Bulgaria, any person is entitled to request and obtain public interest information from the public authorities and institutions. Also, the public authorities and institutions must ensure for persons the public interest information requested in writing or verbally.

In Romania, for the information requested verbally, the information may be supplied on the spot. In case the information requested is not available at the time, the person is instructed to request in writing the public interest information. In what concerns Bulgaria, in case of the verbal request, the information may be supplied on the spot. In case the petitioner considers that the information divulged is not sufficient, or he/she is not offered an answer, he/she may submit a written request.

The necessary information for the access request are the same in both countries, except for the preferred form of access to the information requested, which is requested only in Bulgaria.

Unlike Bulgaria, where the answer to the petition requesting information is given within maximum 14 days since the registration date, in Romania the term is of 10 days, respectively 30 days since the registration date, depending on the difficulty, complexity, volume of documentary works and the urgency of the request.

The law regarding free access to public interest information in Bulgaria indicated the fact that the persons with disabilities of sight, hearing or speech have the right to request the information in a form that corresponds to their ability to communicate, while the law in Romania does not establish such an advantage for the persons with disabilities. In what concerns the sanctions granted for the refusal to offer the information requested, in Romania disciplinary measures are taken, while in Bulgaria the respective public servant will have to pay a certain fine, depending on the gravity of the situation.

\section{Conclusions}

Informing the public with respect to their rights and promoting a culture of governmental transparency are essential for reaching the goals of the regulation regarding the

\footnotetext{
${ }^{7}$ Article 2 of the Law no. 544/2001, regarding free access to public interest information, published in the Official Gazette no. 663/23 October 2001.
} 
freedom of information. Indeed, the experience of both countries ${ }^{8}$ proves that a body of stubborn public servants may undermine even the most progressive legislation. The law should establish the granting of special attention and adequate resources to promote the goals of legislation in force. Freedom of information represents an essential right for each person, allowing individuals and groups to protect their rights, and, at the same time being a useful instrument against defective administration. The legislation in effect, both in Romania and Bulgaria, sets the obligations correlative to the right of information, which are the tasks of the public authorities.

\section{Acknowledgments:}

This work was supported by the strategic grant POSDRU/89/1.5/S/62259, Project "Applied social, human and political sciences. Postdoctoral training and postdoctoral fellowships in social, human and political sciences" cofinanced by the European Social Fund within the Sectorial Operational Program Human Resources Development 2007-2013.

\section{Bibliography}

Bălan, E. \& all, The Right to a Good Administration and its Impact on Public Administration's Procedures, comunicare.ro Publishing House, Bucharest, 2010;

Muraru, I., Tănăsescu, E.S., (coord.), The Constitution of Romania commented article by article, C.H. Beck Publishing House, Bucharest, 2008;

Bălan, E., Procedura administrativă, Universitara Publishing House, Bucharest, 2005;

Constantinescu, M. \& all, (2004), The Constitution of Romania Reviewed commentaries and explanations, All Beck Publishing House, Bucharest, 2004;

Recommendation (2002) 2 of the Committee of Ministers to member states on access to official documents, adopted by the Committee of Ministers on 21 February 2002 at the $784^{\text {th }}$ meeting of the Ministers' Deputies;

Law no. 544/2001 regarding free access to public interest information, published in the Official Gazette no. 663/23 October 2001;

Access to Public Information Act, promulgated in State Gazette No. 55/7 July 2000, with amendments;

Annual Repports on the State of Access to Information published by the Acces to Information Programme Foundation, available at http://www.aipbg.org/en/publications/annualreports/.

\footnotetext{
${ }^{8}$ For Romania see E. Bălan \& all, The Right to a Good Administration and its Impact on Public Administration's Procedures, comunicare.ro Publishing House, Bucharest, 2010 and for Bulgaria the Repports on the State of Access to Information published by the Acces to Information Programme Foundation.
} 